\title{
AN ANALYSIS OF TRANSLATION METHOD USED IN THE NOVEL EARTH TRANSLATED BY GILL WESTAWAY
}

\author{
Nanda Rizki Ramadhan ${ }^{1}$, Baharuddin ${ }^{2 *}$, Lalu Ali Wardana ${ }^{3}$ \\ University of Mataram \\ * e-mail: bahar@unram.ac.id
}

\begin{abstract}
This research aims at finding what kind of translation methods that are applied to the translated novel Earth on the basis of Peter Newmark's translation method. This research is a qualitative descriptive study. The data were collected in the form of words, clauses, phrases, and sentences contained in the novel Bumi and its translated version Earth that were presented within descriptive qualitative fashion. The finding of this research reveals that the translator employed seven out of eight translation methods proposed by Newmark. Specifically, the finding shows that the translation methods were; word-for-word translation method, literal translation method, faithful translation method, semantic translation method, free translation method, idiomatic translation method, and communicative translation method. Hence, the translation product that appears within the translated novel version has no odd text and the translator comes up with a creative way for certain text and leaves it with a suitable method. The translator overcomes various elements such as linguistic, cultural, and literary device in translating the literary work by choosing particular translation methods that are most effective and appropriate for the source text.
\end{abstract}

Keywords: translation method, novel, earth, Newmark

\section{INTRODUCTION}

Nowadays, the need for translation from another language (Source Language) to other languages (Target Language) has been increasing among people all over the world. As citizens who come from diverse backgrounds across the world people are distinguished by their language, culture, custom, and so forth. As a result, an effort of translation process can be classified as truly important to do in order to understand each other resources.

According to Bussman (1996) states in the Routledge Dictionary of Language and Linguistics, in a broad sense, translation refers to the process and results of rendering from source language (SL) into target language (TL) in the form of text. In a narrow sense, it refers to transferring only a written text into another language rather than interpreting of oral language in the meantime. As a matter of fact, translation is only limited to transferring a form of written text from source language into target language. Therefore, it is natural that the term of interpretation is devoted only to transfer of spoken language from one language to another

Additionally, throughout translation human being has taken advantage to transfer any resources into book version that can be read for many generations. In fact, these days many books consist of lots of information for everyone not only share about scientific work things but also share about literary works such as poetry, novel, short story, and so on. Literary works have indeed become a type of entertainment that is fun, especially, for book lovers and those who like to read. However, for some people that come from different languages and need to understand information lies in literary books that use a foreign language, then the possibility that could happen is they are difficult to get the point of the text or message that they tend to read because they have different languages.

Therefore, a translated version of a book, specifically literary types i.e., novel, is needed for those who are interested in 
this type. Earth is a fiction novel that was translated by Gill Westaway from Indonesia to English. The novel was published in 2019 and took place in Indonesia for the very first publication. Earth tells about a three-teenager's adventure that accidentally travels to another world and they must crack mystery in order to beat their enemy. Westaway in her translated novel using varieties of methods in order to make TL readers have the same understanding concept about the novel as SL readers.

Besides, there are several methods related to translation stuff to analyze the translation method used in translation work such as a method established by Peter Newmark. Newmark in his book that was published in 1988 which he introduced his famous method called Vflat diagram method for translation work. Indeed, by following the shape of alphabet "V", there are two sides divided-left side and right side - and both sides (e.g. wordfor-word, literal translation, faithful translation, semantic translation, adaptation, free translation, idiomatic translation, and communicative translation) are used in this study.

This study is aimed to identify whether the translated version of the novel (Earth) fits well in terms of transferring SL culture, custom, jargon used in the original novel (Bumi) to TL in order to achieve translation accuracy and equivalency. In other words, the methods that Westaway used to translate SL into TL were going to be broken down based on the scope of Newmark's V-flat translation method theory.

\section{RESEARCH METHOD}

This study is classified as descriptive qualitative analysis by comparing the Source Language on Bumi with its translated novel entitled Earth that has been translated into English as the target language on the basis of Newmark's V-flat translation method theory. The data were collected qualitatively in order to describe translation methods used within the translated version in accordance with Newmark's translation methods. Additionally, Cresswell (1994) states that qualitative research is therein the researcher concerned in procedure, meaning, and comprehension obtained over words or footages.

According to William and Chesterman (2002), the targets of a qualitative study are to describe or represent the detail of object matter in some informative manners which can guide audience to many possible things of outcomes as a result that can be occurred. Furthermore, according to Vanderstoep and Johnston (2009) assert that human is a fine instrument to apply in qualitative analysis.

The data were collected through several steps. First, Softcopy files of two novel versions were acquired from the internet. Then, the two versions of the novels which original version, and translated version, which were Bumi by Tere Liye and Earth by Will Gestaway were read intensively and carefully by the researcher that might show the emergence of translation method. Next, the data were obtained randomly from both versions of the novels that represent every chapter. Lastly, the required data were collected by means of marking or some sort of mark on both novels that using translation methods in the area of Newmark V-flat diagram theory

The data in this research were analyzed in the following procedures. First, the text in the SL novel (Bahasa) were compared with the text in TL (English) by reading the two novels and were served in form of the table. Secondly, the emergence of translation method in the context of words, phrases, clauses and sentences is identified and classified based on the translation methods as proposed by Newmark (1988). Thirdly, understanding the meaning of text contained in Indonesian and English terms that experienced translation method in the two 
versions of the novels e.g., original version and translated one, according to their respective cultures. Fourthly, the researcher has provided a description and explanation of the findings of the kinds of methods found and put them into a table in which it contains the number of data, SL text and TL text, and translation method. Lastly, draw conclusions and suggestions specifically to the translator of literary work and generally to all studies related to translation stuff.

\section{FINDING AND DISCUSSION}

The data below show the kind of translation methods used by the translator in order to translate the novel entitled
Earth. In this research, data from both novels were collected in the form of words, phrases, clauses, and sentences to show the emergence of translation methods. In addition, there were seven out of eight translation methods proposed by Newmark (1988) used in translating the data from Indonesia into English. They were word-for-word, literal translation, faithful translation, semantic translation, free translation, idiomatic translation, and communicative translation methods. In other words, the researcher found that the translator-Westaway-applied all the methods but Adaptation in her translation work.

Table 1. Translation Methods Used in Translating the Novel Earth

\begin{tabular}{|c|c|c|}
\hline Source Language & Target Text & Translation Method \\
\hline $\begin{array}{l}\text { Mereka mencintai pengetahuan } \\
\text { dan kebijaksanaan (304) }\end{array}$ & $\begin{array}{l}\text { They love knowledge and wisdom } \\
\text { (303) }\end{array}$ & Word-for-word \\
\hline Semakin lebat, semakin seru (13) & The heavier the better (17) & Literal Translation \\
\hline $\begin{array}{l}\text { Tubuhku menjadi lebih bening } \\
\text { dibanding kristal air, menjadi } \\
\text { lebih transparan dibanding tetes } \\
\text { air (14) }\end{array}$ & $\begin{array}{l}\text { My body became clearer than the } \\
\text { crystal of water, more transparent } \\
\text { than the drops of rain }(21)\end{array}$ & Faithful Translation \\
\hline $\begin{array}{l}\text { Enam dari Panglima Pasukan } \\
\text { Bayangan ada di bawah kakinya } \\
(323)\end{array}$ & $\begin{array}{l}\text { He had six of the Commanders of } \\
\text { the Shadow Troops under him } \\
\text { (377) }\end{array}$ & Semantic Translation \\
\hline- & - & Adaptation \\
\hline $\begin{array}{l}\text { Mereka bergegas masuk menuju } \\
\text { bangunan yang kering (13) }\end{array}$ & $\begin{array}{l}\text { They all hurried to get into the } \\
\text { school building out of the rain } \\
\text { (19) }\end{array}$ & Free Translation \\
\hline Sebalku nyaris di ubun-ubun (55) & $\begin{array}{l}\text { I was fed up to the back teeth with } \\
\text { this (69) }\end{array}$ & Idiomatic Translation \\
\hline Kesibukan pagi hari (192)) & Morning rush hour (228) & Communicative Translation \\
\hline
\end{tabular}

\section{The Use of Word-for-word Method}

Newmark (1988) states that in the word-for-word translation method, the words in the target text (Target Text) are usually placed directly under the version of the source text (Source Text), so this translation method is often referred to as the method of translating between lines (interlinear translation).

Table 2. Word-for-word Translation Methods

$\begin{array}{ll}\text { Source Language } & \text { Target Language } \\ \text { Mereka mencintai } & \text { They love } \\ \text { pengetahuan dan } & \text { knowledge and } \\ \text { kebijaksanaan (304) } & \text { wisdom (303) }\end{array}$

The outcome of this translation belongs to word-for-word as text in the source language transferred by word by word in the target language. Pronoun 'mereka' translated to identical pronoun in English as they and verb 'mencintai' into love that categorized as verb in the target text. Noun word of 'pengetahuan' and 'kebijaksanaan' into equivalent word class in the target language 'knowledge' and 'wisdom'. Thus, the translation is still acceptable because it is in accordance with English structure. Likewise, the meaning 
can be understood and accepted in the target language

\section{The Use of Literal Translation Method}

This method of literal translation is independent of context. The translator usually first translates the source text like a word-for-word translation but then adjusts the wording according to the grammar of the target language Newmark (1988)

Table 3. Literal Translation Method

\begin{tabular}{ll} 
Source Language & Target Language \\
\hline Semakin lebat, semakin & The heavier the better \\
seru (13) & $(17)$ \\
\hline
\end{tabular}

The case in the table above shows the adjective phrase 'Semakin lebat, semakin seru' was transferred into 'The heavier the better'. The expression in this text has been translated literally using denotative meanings or according to the meaning of the dictionary and according to the grammar, namely the degree of comparison.

\section{The Use of Faithful Translation Method}

According to Newmark (1988), the translator utilizes the faithful translation when he seeks accurately represent the contextual meaning of the original text within the limits of the target language's grammatical structure. Furthermore, Hartono (2017) comments by employing this translation method, the translator ensures the aspects of format (in legal texts), aspects of form (in poetry texts), metaphorical forms (in literary text translations), and term forms (in informatics texts) are all preserved, allowing the reader to perceive faithfulness in the target language in its original form. This type of translation method stays true to the original text's intent and purpose and follows the form of the source text.
Table 4. Faithful Translation Method

\begin{tabular}{ll}
\hline Source Language & Target Language \\
\hline Tubuhku menjadi lebih & My body became \\
bening dibanding kristal & clearer than the crystal \\
air, menjadi lebih & of water, more \\
transparan dibanding & transparent than the \\
tetes air (14) & drops of rain (21) \\
\hline
\end{tabular}

The SL text 'Tubuhku menjadi lebih bening dibanding kristal air, menjadi lebih transparan dibanding tetes air' using the metaphor as literary device to deliver how the story goes. The original author describes the main characterRaib-body became clear by providing explicit explanation with direct comparison to crystal water that quite clear as we could see our figure reflection reflected in crystal water when winter season hit. The translator stays faithful without a doubt rendered the SL text by following the same literary device into 'My body became clearer than the crystal of water, more transparent than the drops of rain' in hope can create the same nuance as the SL text for the TL readers to result of reproducing contextual meaning. Besides, the translator has adjusted the product of translation in line with TL grammatical constraints since the appearance of the article and of preposition.

\section{The Use of Semantic Translation Method}

Newmark (1988) declares that faithful translation is more rigid and more tied to the source language, while semantic translation is more flexible with the target language. In semantic translation, the translator must consider the aesthetic elements of the source language text by compromising the meaning as long as it is within reasonable limits.

Table 5. Semantic Translation Method

\begin{tabular}{ll}
\hline Source Language & Target Language \\
\hline Enam dari Panglima & He had six of the \\
Pasukan Bayangan ada & Commanders of the \\
di bawah kakinya (323) & $\begin{array}{l}\text { Shadow Troops under } \\
\text { him (377) }\end{array}$ \\
\hline
\end{tabular}


The source text Enam dari Panglima Pasukan Bayangan ada di bawah kakinya was translated to He had six of the Commanders of the Shadow Troops under him. The translator comes up with her intuition in order to sense the source text and catch the real meaning within the text that the original author was intended. The prepositional phrase $d i$ bawah kakinya is semantically transferred into under him in the target text instead of transferring it into under his feet denotatively. The result of the translation is still in line with the real message behind the source text. The original author has employed figurative language in his literary work to describe that Tamus has power or command over others-Panglima Pasukan Bayangan - in the context of the story. Panglima Pasukan Bayangan or the Commanders of the Shadow Troops in translated text are Tamus' men that listen to Tamus order. Therefore, the original author using the prepositional phrase $d i$ bawah kakinya to indicate that Tamus is superior implicitly and the translator overcomes the source text with produces precise meaning that matched the source text.

\section{Adaptation Method}

Newmark (1988) states that this adaptation method is called the freest form of translation and closest to the target language (p. 46). In this adaptation translation process, the source language culture shifts to the target language and the source text is rewritten, and then adapted into the target text. Furthermore, Hoed (2006) adds that in the method of adaptation, cultural elements in the source language are substituted with cultural elements in the target language. In this research, the researcher did not found the culture-related text within the SL text that was translated using the equivalent culture in the target text. Indeed, the original author narrates his novel with a number of SL cultural features yet the outcome of the translation does not appear to translate it with the equivalent culture in the TL. This is due the fact that the SL text cultureIndonesia-has a significant cultural difference with English as the TL text. Newmark (1988) declares that in order to achieve equivalent effect or meaning in TL text is desirable but it can be unlikely to achieve in case where if there is a pronounced cultural gap between the SL and the TL text (p. 48). Furthermore, the difficulties in the cultural aspect occur when translators have trouble finding equivalent terms related to material culture, cultural events, customs, and sociocultural understandings that appear in the original story. Nababan (2003) gives example in his book about the different uses of yes and yea in American English. Translators must be able to find out the equivalent in TL. This will be difficult to do if a SL word does not yet or does not have an equivalent in TL, which is caused by the different cultures of the users of the two languages In this research, the researcher found that culture-related text within the SL text was translated it literally and communicatively. For instance, the SL text Kita makan batagor saja, ya. According to Kamus Besar Bahasa Indonesia batagor is branded as word of acronym stands for bakso tahu goreng from Bandung. Moreover, batagor is a typical Bandung food made from tofu filled with meatball dough then fried, given peanut sauce or meatball sauce. Typical food or regional specialties are classified as part of a functional culture that makes a regional easily recognizable as different from others. The translator rendered it into Let's eat batagor (fried meatballs with tofu) instead, OK literally using denotative meaning upon dictionary in the TL text by adding extra information about the acronym in the form of bracket. Another example of a case that contains culture-related content within the SL text is the sentence Aku meraih payung di belakang kursi, mencium tangan papa, membuka pintu mobil, lalu beranjak turun. The phrase mencium tangan points out the 
tradition or the culture in the moment of farewell in Indonesians. Usually, younger ones kissed the backhand of the older ones as sign of respect. The TL text I took the umbrella from behind the seat, kissed Dad goodbye, opened the car door and go out of the car demonstrates the way westerns people act when it comes to the moment of saying 'goodbye'. In this case 'kissed Dad goodbye' covers the action of kissing in cheeks that Raib showed to her Dad when they reached her school and be apart in a favor way thus make readers find no ambiguity or difficulty to understand it. However, between the two-phrase mencium tangan papa and kissed Dad goodbye are not equivalent even though the two hold the same context in the moment of goodbye. Indonesians do this sign to pay respect from the younger to the older ones meanwhile westerners can do the 'kiss' practically by the same age. Hopefully, the TL reader reads the text with the same degree of interest as the SL reader, although the impact is different Newmark (1988).

\section{The Use of Free Translation Method}

Newmark (1988) asserts that in free translation, the translator tries to translate matter without the manner and/or the content without its original form. The result of translation with this method is usually in the form of a paraphrase that is longer than the original form.

Table 6. Free Translation Method

\begin{tabular}{ll} 
Source Language & Target Language \\
\hline Mereka bergegas & They all hurried to \\
masuk menuju & get into the school \\
bangunan yang & building out of the \\
kering (13) & rain (19)
\end{tabular}

Take a look at the noun school building in the translated text that specifically the word of school did not occur in the SL text since the original author did not explain what kind of building was in his narration. The translator explicitly put extra word school to affects the TL readers that they enter the building of the school in order to make it clear for TL readers. Next, the translator in her work paraphrases the form of clause bangunan yang kering become out of the rain. The dependent clause out of the rain automatically modifies the school building that implies the area within the school building is not wet because of the downpour. By all means, the appearance of the dependent clause out of the rain clears the surface for TL readers broadly and still holds the same contextual meaning with the SL text. In fact, the translator paraphrases the SL text in an effort to allow TL readers to get the message thus the translated and original versions have the same bound meaning.

\section{The Use of Idiomatic Translation Method}

Newmark (1988) suggests that idiomatic translation reproduces messages in TL text with more natural and familiar expressions than SL text. Truly idiomatic translation does not look like translations. The translation results are as if they were written directly from a native speaker.

Table 7. Idiomatic Translation Method

\begin{tabular}{ll} 
Source Language & Target Language \\
\hline $\begin{array}{l}\text { Sebalku nyaris di } \\
\text { ubun-ubun (55) }\end{array}$ & $\begin{array}{l}\text { I was fed up to the } \\
\text { back teeth with this }\end{array}$
\end{tabular}
(69)

The source text Sebalku nyaris di ubun-ubun was rendered into I was fed up to the back teeth with this. In the source text, the origin author recounts how the story goes by adding the phrase ubun-ubun to point out that Seli is quite pissed off toward Ali since Ali treats her as a joke. Usually, Indonesians frequently uses the phrase ubun-ubun to express that they are quite affected by something. For instance, Nanda merasakan sakit hingga ke ubunubun signals that Nanda is in state of pain. As a result, the translator renders the phrase ubun-ubun within the idiomatic translation method as to the back teeth. 
According to Cambridge Dictionary fed up to the back teeth is an expression that is identical to 'very fed up' thus classified as an idiom expression. Therefore, the idiom expression in the target text is identical in contextual meaning with the idiom expression in the source text.

\section{The Use of Communicative Translation Method}

Newmark (1988) states that communicative translation seeks to translate the contextual meaning in SL texts, both linguistic aspects, and content aspects so that they can be accepted and understood by the target language readers. This method is very attentive to TL readers who do not expect difficulties and ambiguity in the translated text.

Table 8. Communicative Translation Method

\begin{tabular}{ll}
\hline Source Language & Target Language \\
\hline $\begin{array}{l}\text { Kesibukan pagi hari } \\
\text { (192) }\end{array}$ & Morning rush hour \\
\hline
\end{tabular}

The translator comes up with the familiar term in the target text. The emergence of Kesibukan pagi hari in the original novel as a result of the author trying to describe how quite busy people at the train station to travel from one place to another in weekday's morning that happens within the novel story. Meanwhile, the noun rush hour refers to one of the very busy times within a period of the day on roads, trains, etc. (Cambridge Dictionary.com). Moreover, the very first-time well-known use of rush hour was in 1878 as reported in MerriamWebster and makes western people familiar with it since then. Hence, the translator puts word morning before the rush hour in order to match with the source text. In conclusion, the translation result meets the criteria of the communicative translation method that make the target readers easily catch its meaning and does not make it difficult to understand.

\section{CONCLUSION}

Westaway's translated novel contains several translation methods as she tries to complete her work in translation. Based on the finding and discussion in the previous chapter, it reveals that Westaway employed seven out of eight translation methods proposed by Newmak. The entire data were made up by the group of methods that emphasis to the SL and were possessed by the group of methods that emphasis to the TL. Additionally, seven translation methods were; word-for-word, literal translation, faithful translation, semantic translation, free translation, idiomatic translation, and communicative translation. The seven translation methods altogether found across forty-five chapters as the researcher required it randomly. However, there is no case for adaptation since in adaptation method requires the source text that features culture-related text must be translated into the equivalent culture in the target text. Although there is several culture-related within the source text yet the product of translation did not appears to represent equivalent target text's culture instead just translates it literally and communicatively. Eventually, the translation methods applied are able to produce accurate, acceptable, and natural translations in the target language and are easily understood by the target readers.

Based on the research that has been done, the researcher put the following suggestion;

Translators are advised to translate literary works such as novels must be able to carefully choose a method that prioritizes the accuracy and completeness of information so that the readers can understand the implied message because not all readers have the same cultural and scientific background. Translating novels does not seem as easy as translating plain text. Many novel translators face difficulties when translating them. These difficulties cover various aspects, including linguistic aspects, cultural aspects, and literary aspects thus choosing 
a certain method to be applied will take a big role that affected the product of translation

Future researchers who would like to analyze translation method in the novel are suggested that they should analyze translation method in different fashion in order to collect the data based on the structure of events that make up a fictional story (e.g. exposition, conflict, climax, and resolution). It should keep in mind that the varieties of translation methods are not restricted to the eight methods suggested by Newmark, but there are several types of translation methods proposed by various experts that can also be analyzed and studied. This research, hopefully, can be utilized as a reference and source for other relevant studies that address translation and, in particular, translation methods as the main topic in order to perform better research on different types of translation methods.

\section{REFERENCES}

Bussman, H. (1996). Routledge Dictionary of Language and Linguistics. New York: Routledge Ltd.
Creswell, J. W. (1994). Research Design Qualitative and Quantitative Approaches. London: Sage Publications.

Hartono, R. (2017). Pengantar Ilmu Penerjemah. Semarang: Cipta Prima Nusantara.

Hoed, B. (2006). Penerjemahan dan Kebudayaan. Bandung: PT Kiblat Buku Utama.

Nababan, M. (2003). Teori Menerjemah Bahasa Inggris. Yogyakarta: Pustaka Pelajar.

Newmark, P. (1988). A Book of Translation. Prentice Hall.

VanderStoep, S. W., \& Johnston, D. (2009). Research Methods for Real Life: Blending Qualitative and Quantitative Approaches. San Francisco: Jossey Bass.

Williams, J., \& Chesterman, A. (2002). The Map: A Beginner's Guide to Doing Research in Translation Studies. St. Jerome Publishing. 